\title{
W (niedomkniętym) kręgu teorii Erazma Kuźmy
}

\section{O konstruktywizmie, regionalizmie, autobiografizmie, a także innych wątkach w badaniach szczecińskiego literaturoznawcy, rozmawiają Jerzy Madejski, Andrzej Skrendo, Bogdan Balicki i Stawomir Iwasiów}

DOI: http://dx.doi.org/ 10.12775/LC.2016.045

Bogdan Balicki: W 2006 roku, nakładem Wydawnictwa Universitas, ukazała się książka Konstruktywizm w badaniach literackich. Antologia, którą zredagowali wspólnie Profesor Erazm Kuźma oraz obaj obecni tu Panowie, Jerzy Madejski i Andrzej Skrendo. Ta antologia nie posiada precedensu, przede wszystkim dlatego, że to pierwsze tego typu wydawnictwo zbierające polskie przekłady tekstów konstruktywistycznych. Poza tym jest to rzecz bardzo dobrze sprofilowana pod względem metodologicznym, spójna jeśli chodzi o wizję tego, czym konstruktywizm może być dla literaturoznawstwa czy nawet szerzejhumanistyki.

Chciałbym zapytać Panów, jak wspominacie, z perspektywy dekady mijającej od momentu wydania, przebieg prac nad tym tomem? Jakie były konteksty redagowania tych tekstów?

Jerzy Madejski: Konteksty prac nad książką były przynajmniej dwa - anegdotyczny oraz instytucjonalny.

Ten pierwszy jest bardzo prosty: Kuźmę zainspirował Ryszard Nycz, który znał zainteresowania badawcze Profesora związane z konstruktywizmem i zachęcił go do podjęcia projektu stworzenia antologii. Kuźma zadeklarował, że sam nie będzie tego robił - zależało mu na pracy zespołowej. Zaproponował nam w związku z tym, żebyśmy wspólnie przystąpili do działań koncepcyjnych i redakcyjnych.

Niewątpliwa była zatem rola w tym przedsięwzięciu Ryszarda Nycza, który chciał mieć w „Horyzontach Nowoczesności” - i to jest ten drugi, instytucjonalny kontekst antologię tekstów konstruktywistycznych. 
Bogdan Balicki: Czyli pomysł przyszedł z centrali?

Jerzy Madejski: Jeśli Kraków uznamy za „centralę”, to tak. Oczywiście trzeba podkreślić, że ten koncept $\mathrm{w}$ ogóle by się nie pojawil, gdyby nie przymiarki Profesora do konstruktywizmu literaturoznawczego i socjologicznego - głównie w wariancie Niklasa Luhmanna. Natomiast nieco wcześniej, zanim powstał Konstruktywizm $w$ badaniach literackich, mieliśmy w planach wydanie szczecińskiego, konstruktywistycznego numeru czasopisma „Er(r)go”. $\mathrm{Z}$ różnych powodów to się nie udało, ale niektóre pomysły przenieśliśmy później do antologii.

A sama praca nad tomem? W skrócie: szaleńcza. To wciąż jeszcze były czasy, kiedy zdobycie oryginalnych tekstów stanowiło wyzwanie. Korzystaliśmy między innymi z uprzejmości naszego kolegi z Instytutu Filozofii, Jaromira Brejdaka, który przywiózł nam trochę książek konstruktywistycznych, w tym Niklasa Luhmanna i Ernsta von Glasersfelda.

Andrzej Skrendo: Wspominam naszą współpracę nad tą książką podobnie jak Jerzy - atmosfera była, delikatnie rzecz ujmując, gorączkowa. Dzisiaj pewnie zrobilibyśmy wszystko inaczej... Upłynęło dwanaście, trzynaście lat od momentu, kiedy wzięliśmy się za tę antologię. To w gruncie rzeczy odległa epoka.

Sławomir Iwasiów: Jeśli można, chciałbym wtrącić krótką uwagę na temat tej książki. Mimo że w żaden sposób nie brałem udziału w jej tworzeniu, to pamiętam, że była ona dla mnie pierwszym, jeszcze studenckim zetknięciem z konstruktywizmem. Wcześniej to pojęcie na szczecińskich studiach polonistycznych raczej się nie pojawiało. Natomiast mniej więcej w czasie, kiedy został wydany ten tom, za pośrednictwem jego redaktorów dowiedziałem się o teorii konstruktywistycznej i możliwościach jej wykorzystania w literaturoznawstwie. W jakimś sensie zatem był to moment przełomowy, a konstruktywizm do dzisiaj jakoś tam funkcjonuje w szczecińskim kręgu, choćby w kształceniu studentów dziennikarstwa.

Bogdan Balicki: Antologia dzieli się na trzy części, przy czym każda z nich ma jednego, wyraźnego redaktora. Wstęp i pierwsza część - poświęcona koncepcjom Niklasa Luhmanna - zostały przygotowane przez Erazma Kuźmę. Część drugą, pisma Siegfrieda J. Schmidta, opracował Andrzej Skrendo, natomiast trzecią - której bohaterami są Steven Tötösy de Zepetnek i Ernst von Glasersfeld - zredagował Jerzy Madejski.

Jerzy Madejski: Ten układ wynikał z naszej dłuższej przygody intelektualnej z konstruktywizmem. To, że akurat zajmowaliśmy się tymi teoretykami i zagadnieniami a więc różnymi wariantami myślenia konstruktywistycznego - stanowiło wynik wielu spotkań, dyskusji, negocjacji. Poza tym zdawaliśmy sobie sprawę, że atmosfera wokół konstruktywizmu stawała się coraz bardziej, by tak rzec, „gorąca”. Inne ośrodki w Polsce też podejmowały namysł nad konstruktywizmem, wydawano po polsku tłumaczenia książek Luhmanna i pojedyncze teksty innych konstruktywistów.

Andrzej Skrendo: Musimy być świadomi, że w tamtym okresie były przetłumaczone na język polski może ze dwa teksty Schmidta, a i one nie dawały właściwie żadnego sensownego pojęcia o tym, kim jest Schmidt, na czym właściwie polega konstruktywizm i jak może się - jako wyrazista teoria - przysłużyć badaniom nad literaturą. W tym sensie stąpaliśmy po słabo zbadanym terytorium.

Jerzy Madejski: Nade wszystko jednak podział był podyktowany względami pragmatycznymi. Musiało się w tomie znaleźć miejsce na rozdział ogólny, wprowadzający do 
teorii konstruktywizmu - Profesor miał w tej materii najlepsze rozeznanie. Musiał być dział poświęcony zastosowaniom literaturoznawczym konstruktywizmu - stąd Tötösy de Zepetnek, którego nastawienie komparatystyczne i rozeznanie w kilku literaturach narodowych dawało szerokie spojrzenie na aplikacje konstruktywizmu w badaniach literackich. I wreszcie Schmidt - przede wszystkim dlatego, że wcześniej jego koncepcje zaadaptował strukturalizm, co w części trzeciej antologii zrekonstruował Andrzej.

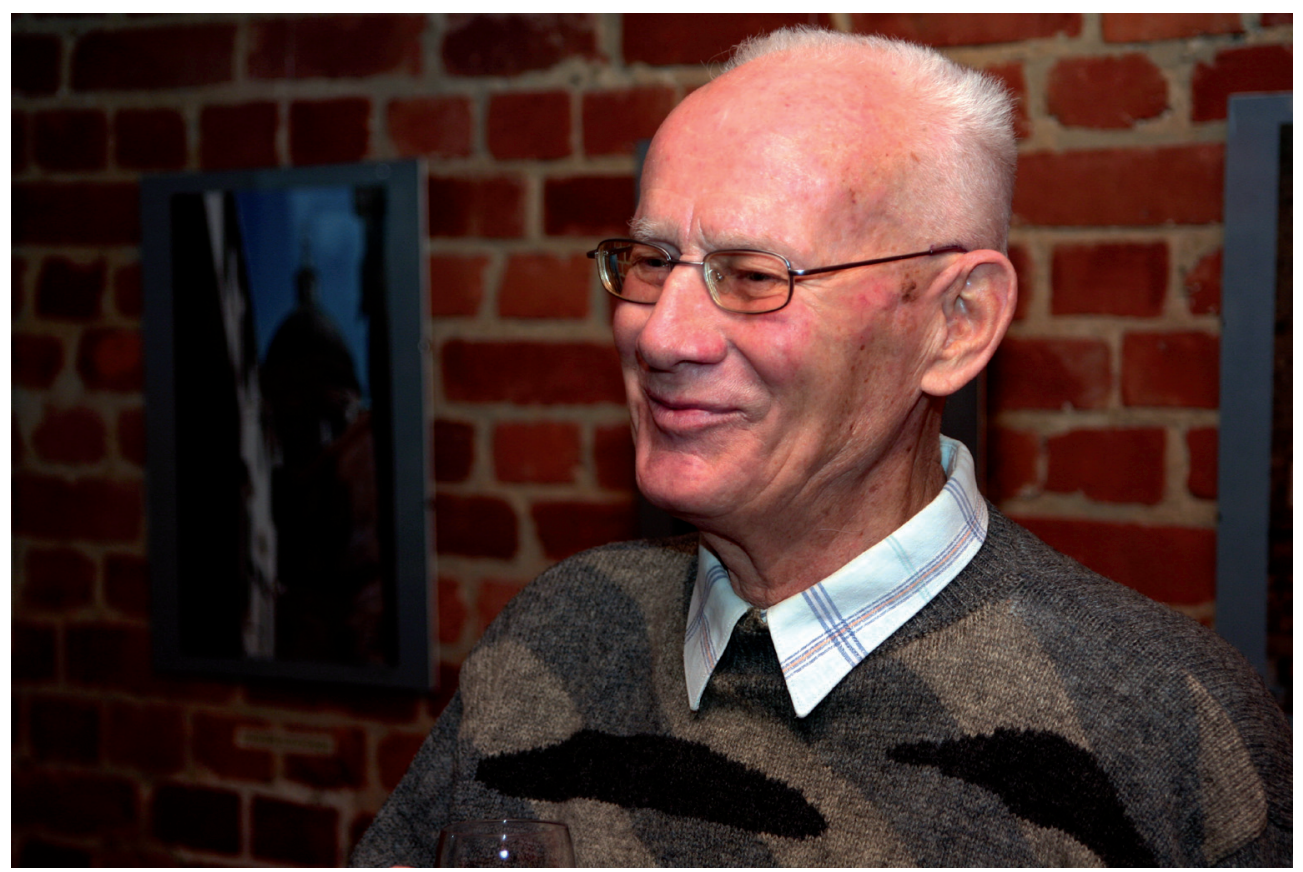

Bogdan Balicki: Opierając się na doświadczeniach we współredagowaniu późniejszego niż wasz tomu, Radykalny konstruktywizm. Antologia, muszę przyznać, że Konstruktywizm $w$ badaniach literackich daje bardzo dobry wgląd $w$ teoretyczne zagadnienia związane z niemieckim konstruktywizmem, zarówno w wydaniu Schmidta, jak i Luhmanna. Zepetnek wydaje mi się w tym zestawieniu nieco tajemniczy, choć to kwestia na marginesie ogólnego pozytywnego wrażenia, które książka pozostawia po lekturze. Czy Panowie potrafią dzisiaj zrekonstruować, jak przebiegał proces doboru tekstów do antologii?

Jerzy Madejski: Wyjaśnię tylko Pańską wątpliwość: obecność Zepetneka należy widzieć w perspektywie związków konstruktywizmu z komparatystyką. Wpływowym głosem w literaturoznawstwie światowym przełomu XX i XXI wieku była jego książka Comparative Literature: Theory, Method, Application.

Andrzej Skrendo: Kiedy robiliśmy tę antologię, stan wiedzy o konstruktywizmie był zupełnie inny niż teraz. Glasersfeld był nieznany. Schmidt wprawdzie funkcjonował, ale jak powiedzieliśmy wcześniej - w niejakim oderwaniu od konstruktywizmu. Luhmann był w świecie literaturoznawczym słabo rozpoznany, może coś na jego temat wiedzieli socjologowie. Zepetnek, mimo kariery międzynarodowej, właściwie do dzisiaj w Polsce się nie przyjął, z wyjątkiem badań komparatystycznych. 
Byliśmy jednakowoż świadomi, że konstruktywizm jest nurtem o wiele szerszym niż możliwości aplikacyjne literaturoznawstwa. Musieliśmy dostosować zebrane w tym tomie teksty do problematyki literaturoznawczej. Poza tym - co wydaje mi się równie istotne - ci autorzy otwierają różne pola literaturoznawczego wykorzystania konstruktywizmu. Luhmann - na polu socjologii i filozofii, Schmidt - medioznawstwa, Glasersfeld pedagogiki, Zepetnek - komparatystyki. Stąd, jak podkreślił wcześniej Jerzy, ten ostatni autor jest ważnym ogniwem w tym zestawie, ponieważ uzupełnia szerokie pola literaturoznawczych kompetencji. A zatem dużą część wiedzy na temat konstruktywizmu i jego okolic, które kilkanaście lat temu były dla nas nowością, zdobywaliśmy podczas prac nad antologią, a także - w dużej mierze - dzięki współpracy z Profesorem.

Bogdan Balicki: Właśnie, chciałbym teraz - przynajmniej na moment - zmienić kierunek rozmowy i skupić się na postaci Erazma Kuźmy. Sławku, jak z punktu widzenia kogoś, kto stosunkowo niedawno był studentem szczecińskiej polonistyki, postrzegasz osobowość naukową i dydaktyczną Profesora?

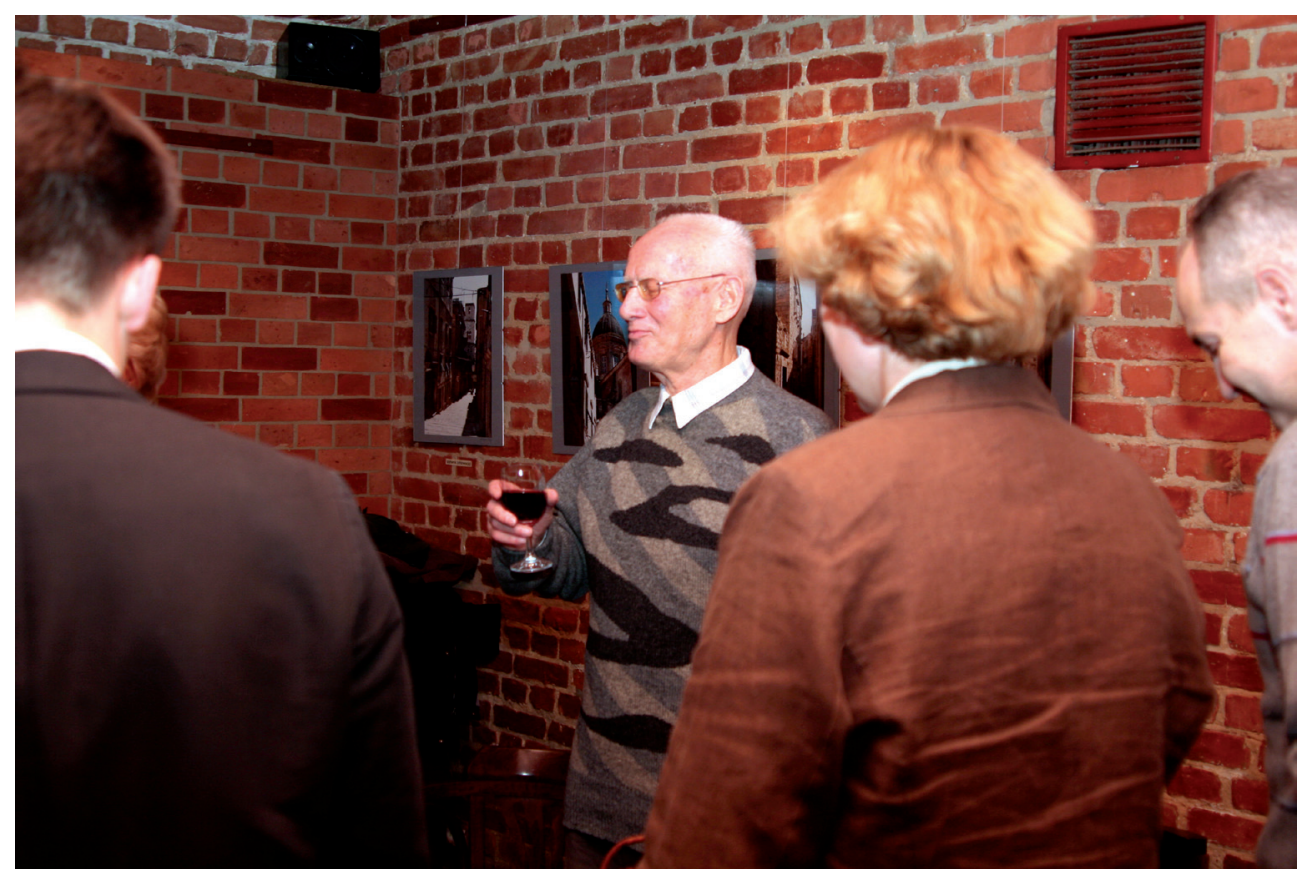

Sławomir Iwasiów: Zacząłem studia w 2003 roku i od początku miałem świadomość, że Erazm Kuźma jest postacią nietuzinkową. Czytaliśmy jego teksty, choćby na zajęciach $\mathrm{z}$ analizy i interpretacji dzieła literackiego - w programie kanoniczną lekturą był, i wciąż jest, artykuł Spór o wartość i zasadność interpretacji literackiej. Poza tym za Profesorem po korytarzach uczelni podążała legenda, którą szybko miałem okazję zweryfikować, mimo że nigdy nie chodziłem na jego zajęcia. Profesor Madejski zabrał nas, studentów pierwszego roku, na jedno z okolicznościowych seminariów Zakładu Teorii Literatury, chyba właśnie w 2003 roku, w okresie przed Bożym Narodzeniem. Profesor

1 E. Kuźma, Spór o wartość i zasadność interpretacji literackiej, „Pamiętnik Literacki” 1989, z. 80/3, s. 3-18. 
Kuźma wygłaszał na tym seminarium referat, którego treści za nic sobie nie przypomnę. Nade wszystko jednak doskonale zapamiętałem, jak duże wrażenie wywołała na mnie postać referenta - teoretyka literatury, który potrafil porwać słuchaczy, niejako „zapraszając" ich do dyskusji, a nie tylko wygłaszając tak czy inaczej sformułowane tezy.

Bogdan Balicki: Podobne pytanie chciałbym skierować do Panów, ponieważ jestem ciekaw, jakie elementy osobowości Profesora sprawiły, że dzisiaj, chyba jednogłośnie, mówi się o nim jako o twórcy szczecińskiej tradycji polonistycznej.

Jerzy Madejski: To pytanie jednak nie dotyczy tylko konstruktywizmu, ale przede wszystkim autobiografizmu ... My tu mówimy o konstruktywizmie - jako o metodzie a przecież we wcześniejszych tekstach Profesora można odnaleźć pewne elementy, nazwijmy to tak, niezbywalnej „konstruktywności”. Wiąże się to, rzeczywiście, z kwestiami autobiograficznymi.

Profesor to Wielkopolanin, który przyjechał do Szczecina na początku lat 50. i zastał miasto, które częściowo wciąż stało w gruzach. Zniszczone były katedra pw. św. Jakuba Apostoła i Zamek Książąt Pomorskich. Wciąż wywożono ze Szczecina różne dobra... Jeszcze niedawno tu był Stettin, więc wśród nowo przybyłych mieszkańców musiała utrzymywać się niechęć do wszelako pojmowanej „germańskości”. Trzeba zdawać sobie sprawę z tego, że w regionie wielkopolskim antyniemieckość była niezwykle silna, co widać w tekstach innych pionierów, którzy po wojnie przyjechali do Szczecina z Wielkopolski - myślę tu choćby o Piotrze Zarembie, pierwszym prezydencie miasta, czy prawniku, Romanie Łyczywku. W ich książkach nienawiść do Niemców bywa wprost wyrażana, z czego zresztą musieli się, w kolejnych dekadach, rozliczać. Nie pamiętam, żeby Profesor tak mówił o Niemcach. A warto przypomnieć, że w czasie wojny w rodzinnym Wągrowcu młody Erazm uciekał przed niemieckim pościgiem, skacząc do Jeziora Durowskiego. I tylko dzięki tężyźnie fizycznej Kuźma (miał przydomek „Kusociński”2) wybawił się z opresji.

Ale wyobraźmy sobie: Erazm Kuźma przyjeżdża do Szczecina po studiach w Poznaniu. Pracuje jako nauczyciel w II LO i tu musi „zbudować” świat powojenny. Jak to robi? Przez literaturę, między innymi pisaną piórem szczecińskich poetów. Takich jak Tymoteusz Karpowicz, który oswajał Pomorze Zachodnie przez kolejne mity: Odry, Bałtyku, Ziem Odzyskanych. Profesor je krytycznie analizował, głównie jako krytyk. Znamienna jest antologia Nazywanie ziemi. Ziemia Szczecińska w poezji ${ }^{3}$, gdzie zostały zebrane różne reprezentacje tych powojennej mitologii czy mitografii Szczecina. I to jest właśnie konstruowanie, charakterystyczne dla twórczości Erazma Kuźmy, który - należy to podkreślić - był świadomy, że konstruuje. Na tym polega owa „konstruktywność”. I z takim nastawieniem Kuźma traktował wtedy, w tekstach krytycznych, wspomnianego Karpowicza, ale też Helenę Raszkę, Joannę Kulmową i innych poetów.

Bogdan Balicki: Czyli w jakimś sensie twórca był dla Kuźmy „wytwórcą” rzeczywistości?

Jerzy Madejski: Można by i tak to ująć. Dużo później - nie tylko dlatego, że było to trudne w ówczesnych warunkach instytucjonalnych i politycznych - Kuźma zaintere-

\footnotetext{
2 Janusz Kusociński (1907-1941), lekkoatleta, m.in. zdobywca złotego medalu na olimpiadzie w Los Angeles w biegu na 10000 m i srebrnego medalu na mistrzostwach Europy w Turynie w biegu na $5000 \mathrm{~m}$.

3 Nazywanie Ziemi. Ziemia Szczecińska w poezji, wyboru wierszy dokonał E. Kuźma, wybór grafiki i opracowanie graficzne I. Naruszewicz, Wydawnictwo Poznańskie, Poznań 1970.
} 
sował się literaturą pomorską, niemiecką, pisaną przed 1939 rokiem. Znał ją oczywiście wcześniej, ponieważ w latach 70. napisał książkę Z problemów świadomości literackiej i artystycznej ekspresjonizmu $w$ Polsce $e^{4}$. I to był ten element konstruktywistyczny czy może raczej prekonstruktywistyczny, chociaż dla pełni obrazu trzeba by wziąć pod uwagę filozoficzne aspekty ekspresjonizmu, który jest podbudowany mitami niemieckimi, zainteresowaniem ziemią...

Bogdan Balicki: Jak w takim razie przebiegało konstruowanie szczecińskiej polonistyki?

Jerzy Madejski: Wie Pan, to jest długa opowieść i prawdę mówiąc - wzruszająca. Jest z nią pewien kłopot, bo dzisiaj nie wszyscy chcą się zgodzić na niektóre jej wątki, powstaje konkurencja w wyścigu o pionierski laur. Tak czy inaczej, na tle regionu Profesor był, nie ma co ukrywać, gigantem. Nie było wątpliwości, że to ktoś otwarty na dyskusję, na debatę - ktoś, kto nigdy nie wahał się, żeby poświęcić czas na rozmowę o wierszach, esejach, monografiach. Dzisiaj nie dla wszystkich jest to oczywiste.

Myśmy w latach 80. spędzali czas w małym pokoju, w budynku uniwersytetu przy ulicy Tarczyńskiego, ale nie tylko dlatego, że Profesor tak bardzo chciał z nami przesiadywać. Miał bowiem gest „dyrektorski”s: lubił swój gabinet - z biurkiem stojącym w odpowiednim miejscu, trzymał w szafce zawsze przygotowaną do poczęstunku brandy, organizował zebrania zakładowe. Lata 80 . były jednak posępne. Gdy powstał Uniwersytet Szczeciński (1985), Profesor został odsunięty na bok, przestał być dyrektorem Instytutu. A uniwersytet w Szczecinie to było przecież jego marzenie.

I właśnie: w tym naszym pokoiku, w niezbyt komfortowych warunkach - przestrzennych oraz administracyjnych i politycznych - byliśmy świadkami i uczestnikami rozmów dużego kalibru. Bywali u nas filozofowie, m.in.: Henryk Hadryś i Wacław Mejbaum 7 . Wpadał Karol Koczy ${ }^{8}$, germanista, i wielu innych. Trwała poważna robota filologiczna. Pracowali z nami wtedy i Mirosław Lalak ${ }^{9}$, i Ireneusz Sikora ${ }^{10}$. W drugiej połowie lat 80 . obmyślaliśmy różne publikacje dla Wydawnictwa Glob, między innymi tom Autor i jego wcielenia. Szkice o roli autora w literaturze. Kuźma

4 E. Kuźma, Z problemów świadomości literackiej i artystycznej ekspresjonizmu w Polsce, Zakład Narodowy im. Ossolińskich, Wrocław 1976.

${ }_{5}$ Profesor był dyrektorem szczecińskiej polonistyki w pierwszej połowie lat 80. i pierwszej połowie lat 90. XX wieku.

6 Henryk Hadryś (1950-2003), filozof, autor prac z zakresu teorii poznania, metodologii i historii nauki. Kierował Zakładem Filozofii Nauki w Instytucie Filozofii Uniwersytetu Szczecińskiego.

7 Wacław Mejbaum (1933-2002), filozof, autor wielu prac z zakresu teorii poznania, filozofii języka, metodologii, materializmu historycznego. W drugiej połowie lat 80. i w latach 90. XX wieku dyrektor Instytutu Filozofii Uniwersytetu Szczecińskiego.

8 Karol Koczy (1932-2015), germanista, metodyk nauczania języka niemieckiego, tłumacz; twórca uniwersyteckiej germanistyki w Szczecinie; był pierwszym dyrektorem Instytutu Germanistyki Uniwersytetu Szczecińskiego.

9 Mirosław Lalak (1955-1999), współzałożyciel i pierwszy redaktor pisma „Pogranicza”. Autor książek: Między historia a biografią. O prozie Stanisława Rembeka, Wydawnictwo Naukowe Uniwersytetu Szczecińskiego, Szczecin 1991; Niepokojąca reszta. Szkice krytyczne, wybrał, opracował i wstępem opatrzył A. Skrendo, Wydawnictwo 13 Muz, Szczecin 2004. Redaktor i współredaktor tomów zbiorowych: Autor i jego wcielenia: szkice o roli autora w literaturze, red. E. Kuźma, M. Lalak, Wydawnictwo Glob, Szczecin 1991; Wizje końca świata w literaturze, red. M. Lalak, Wydawnictwo Naukowe Uniwersytetu Szczecińskiego, Szczecin 1992; Z problemów podmiotowości w literaturze polskiej XX wieku, red. M. Lalak, Wydawnictwo Naukowe Uniwersytetu Szczecińskiego, Szczecin 1993.

10 Ireneusz Sikora, historyk literatury, pracownik Uniwersytetu Szczecińskiego w latach 80. XX wieku. Autor m.in. książek: Symbolika kwiatów w poezji Młodej Polski, Wydawnictwa Naukowe Uniwersytetu Szczecińskiego, Szczecin 1987; Róże, lilie, tuberozy: młodopolskie wiersze o kwiatach, wybór, układ i wstęp I. Sikora, Wydawnictwo 
czytał nam też wtedy swoje referaty i recenzje, między innymi pisane do „Pamiętnika Literackiego”. Były to tematy oddalone od realiów politycznych, dotyczące mitografizmu, hermeneutyki, dekonstrukcji - to już w późnych latach 80. - i nad tymi tekstami dyskutowaliśmy.

Bogdan Balicki: A gdyby miał Pan określić, jednym słowem, charakter Erazma Kuźmy, to byłby to wódz, nauczyciel, lider?

Jerzy Madejski: W żadnym razie wódz. Można by nawet mieć do niego pewne pretensje, że bywał zbyt mało „wodzowski”. Wiele cząstkowych inicjatyw nie doszło do skutku, ponieważ zwalniał się z obowiązków organizacyjnych. I żeby była jasność: niekoniecznie był najlepszym promotorem, bo niespecjalnie się troszczył o bieżące potrzeby, takie jak pilnowanie terminów.

Bogdan Balicki: A czy można o Kuźmie powiedzieć, że był główną siłą napędową polonistyki w Szczecinie, czy też jednym z wielu równoważnych elementów jej rozwoju?

Jerzy Madejski: Oczywiście to pierwsze stwierdzenie jest trafne, co nie znaczy, że Profesor był zapamiętałym organizatorem polonistyki. Był przekonany, że środowisko się samo z siebie wytwarza, a do tego procesu niezbędna jest jedynie swobodna dyskusja - w tym sensie był to pogląd stricte konstruktywistyczny. Skądinąd wiemy, że tak się ani nie działo wtedy, ani tym bardziej nie dzieje obecnie.

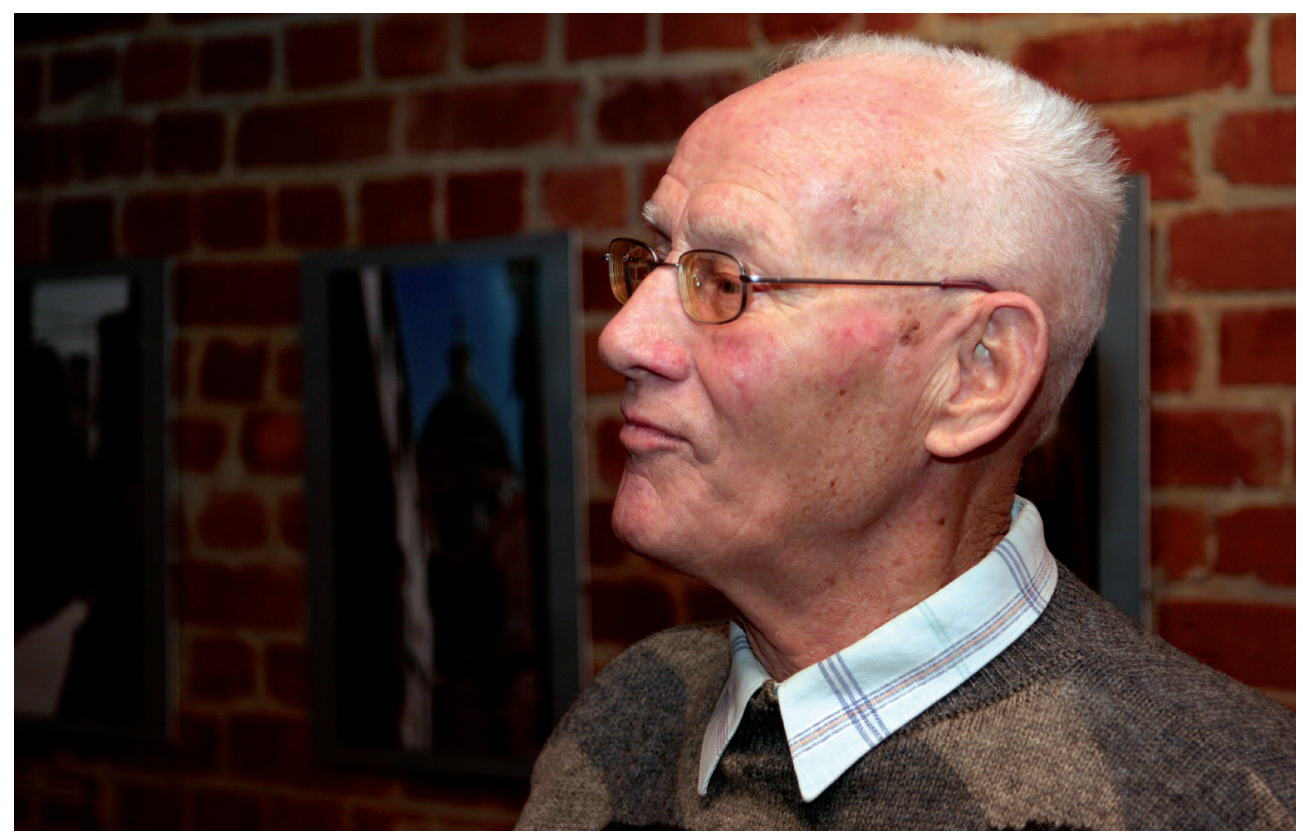

Andrzej Skrendo: Erazm Kuźma bez wątpienia stworzył nie tyle szkołę, co swego rodzaju styl myślenia o literaturze, do którego każdy mógł się wpisać - i nie była to przynależność na stałe wiążąca. Jego zapraszający gest był zachętą do oporu, sprzeciwu, niezgody.

Glob, Szczecin 1988; Przyroda i wyobraźnia. O symbolice roślinnej w poezji Młodej Polski, Wydawnictwo Uniwersytetu Wrocławskiego, Wrocław 1992. 
Profesor był osobowością paradoksalną: nie miał w sobie cech przywódcy, ale świetnie przewodził. Nie szukał uznania, nie wymagał w książkach swoich uczniów nawiązań do swoich prac. Przeciwnie - nie lubił tego typu zachowań i je tępił. Nie był typem przywódcy w sensie założyciela „szkoły”, dlatego unikam tego słowa, ale raczej opowiadał się za swobodnym tworzeniem kolektywu myślowego - w znaczeniu, jakie temu pojęciu nadał Ludwik Fleck. Kuźmie absolutnie nie zależało na tym, żeby mieć uczniów. Był przywiązany do idei Zaratustry, który rozgania uczniów, mówiąc, że muszą się go przynajmmniej trzy razy zaprzeć, i dopiero jak się trzy razy zaprą, to do niego wrócą, choć już nie jako uczniowie, ale mistrzowie. Profesor nie prowadził za rękę - i w tym sensie był „złym” promotorem. Wymagał samodzielności, partnerstwa, dojrzałości.

Paradoksalnie właśnie w ten sposób gromadził wokół siebie ludzi, choć przecież nie planował, nie zakładał, nie tworzył żadnej grupy czy szkoły myślenia.

Bogdan Balicki: Czyli było to coś w rodzaju „metody w antymetodzie”?

Andrzej Skrendo: Też, ale przede wszystkim to była metoda majeutyczna. Kuźma uwielbiał dyskutować, spełniał się w rozmowie, w debacie. Zdarzało mi się prowadzić niejedną dobrą rozmowę $\mathrm{w}$ różnych środowiskach akademickich, ale nigdy nie brałem udziału w takich dyskusjach, jak z Profesorem. Pozwalał nam prawie na wszystko: autoironię, opór, złośliwość, nawet na brak szacunku, tupet czy agresję.

Sławomir Iwasiów: Czyli często się kłóciliście?

Andrzej Skrendo: Tak, bezpardonowo! Bez odczucia, że naruszamy jakieś tabu. Wszyscy wiedzieliśmy, że Profesor jest autorytetem, ale w dyskusjach tak go nie traktowaliśmy. Zresztą - źle by się z tym czuł, ponieważ nie lubił tych wszystkich konwenansów, traktowania profesora po profesorsku, wyczuwał w tym fałszywą nutę. Nie mógł znieść gombrowiczowskich nieszczerości w ludzkich relacjach. Oczekiwał czystej ekspresji.

Chciałbym jeszcze nawiązać do tego, co Jerzy mówił o „konstruktywności” Kuźmy. Jego teksty, z definicji, były tekstami konstruktywistycznymi, ponieważ „konstruktywistyczne” było nastawienie ich autora. Kuźma, na wstępie, zawsze mówił: „Wyobraźmy sobie, że jest tak i tak”. Przyjmował taką ramę niezależnie od tego, czy tekst był napisany z punktu widzenia semiotycznego, marksistowskiego czy luhmannowskiego. To też prowadziło do szeregu paradoksów. Kiedy pisał o poetyce rewolucyjnej, stwierdził, że celem tekstu nie jest dowiedzenie czegokolwiek. Brzmi jak żart? Ależ skąd! Przecież koncepcja poetyki rewolucyjnej musi zakładać, że rewolucja nigdy się nie kończy, bo inaczej musiałaby się zamienić w kontrrewolucję. To był sposób na pokazanie i odtworzenie dynamiki procesu tworzenia poetyki rewolucyjnej przy użyciu języka teorii literatury. Kuźma bronił się przed konsekwencjami dochodzenia do konkluzji.

To oczywiście nie pozostawało bez wpływu na daleko posunięte, wręcz bloomowskie „odchylenia” lekturowe. Kuźma, jeśli czytał Nietzschego, Derridę, Luhmanna - czy kogokolwiek innego - nie troszczył się o hermeneutyczną wierność.

W tekście o senioracie literaturoznawców cytował ostrzeżenie Luhmanna, który mawiał: „mój styl jest ironiczny. Chcę przez to powiedzieć: nie bierzcie mnie zbyt serio czy też: nie przytakujcie mi zbyt pochopnie" ${ }^{11}$. Każdy, kto zna abstrakcyjną i ciężką maszynerię stylistyczną Luhmanna wie, jak bardzo paradoksalnie brzmi to zdanie - ale świetnie pasuje do pełnego energii stylu Kuźmy! Kuźma zniekształcał swoje lektury, był

\footnotetext{
11 E. Kuźma, Seniorat literaturoznawców, "Litteraria Copernicana” 2010, nr 1 (5).
} 
mocnym czytelnikiem i robił tak również z konstruktywizmem, który był na usługach jego autokreacji. Realizuje się ona - w teorii Kuźmy - poprzez komunikację, bez transcendencji, immanentnie.

Bogdan Balicki: W tekście Autor jako komediant - pochodzącym z tomu Autor i jego wcielenia ${ }^{12}$, o którym wcześniej wspomniał Jerzy Madejski - Kuźma pisze tak: „Nasz ludzki paradoks polega na tym, że tęsknimy do milczenia, do bytu w sobie, ale i owa tęsknota, i byt w sobie, i milczenie istnieją tylko dzięki językowi, dzięki temu, że jesteśmy bytem dla siebie. Być człowiekiem - to znaczy mówić, a mówić - to znaczy oddalać się od milczenia i bytu w sobie [...]. Wszystko jest brzegiem. Wiecznie woła morze. Wszystko jest milczącą, zamkniętą w sobie rzeczą, bezpiecznym brzegiem. Ale nas, ludzi, wiecznie woła morze. I wyruszamy na nie w chybotliwej łupinie słowa”.

Andrzej Skrendo: I dodałby Kuźma: „Wyobraźmy sobie, że tak właśnie jest”. I dalej, zależnie od etapu, na jakim się znajdował, mówiłby na przykład Heglem przetrawionym przez Sartre’a. Albo: językiem Luhmanna. Dobrze, że cytujesz ten fragment, bo on zdaje sprawę z drogi Erazma Kuźmy, który zaczynał od związków z heglizmem i marksizmem, i w jakimś sensie zawsze pozostawał im wierny. I tak też wchodził w konstruktywizm, ponieważ Luhmann był dla niego w jakimś sensie lepszą wersją Hegla. Zgodziłby się Kuźma z Heideggerem, który - w rozmowie, zdaje się, z jakimś francuskim dziennikarzem - stwierdził, że każdy francuski filozof, jeśli chce być poważny, przechodzi w filozofii na język niemiecki.

Jerzy Madejski: Nie mniej ważne - z punktu widzenia zarówno tego fragmentu, który Pan przytoczyl, jak również innych prac Profesora - są wszelkie koniunktury historyczne. Tekst o rewolucyjności ${ }^{13}$ - jego bohaterką była Julia Kristeva - komentowano na posiedzeniu Komitetu Wojewódzkiego PZPR w Szczecinie. Ten referat był długo niewydany, ponieważ tom po konferencji nie mógł się ukazać. Wtedy Instytutem Badań Literackich kierował Witold Nawrocki. Kiedy przyjechał z "gospodarczą" wizytą do Szczecina, na nowy uniwersytet, to na zebraniu, w naszym instytucie, pojawiły się odniesienia do tych badaczy, którzy nieroztropnie nawiązują do marksizmu i niejako kompromitują naukę polską. Trzeba sobie zatem zdawać sprawę, że prace Profesora powstawały w oporze przeciwko dogmatyzmowi.

Tekst Autor jako komediant ma równie ciekawy kontekst. Swoją drogą - to świetny tytuł! Jak Pan tak czytał tę zgoła poetycką frazę Profesora, to poczułem się trochę tak, jakbyśmy byli na jakimś festiwalu wolnej myśli. A przecież ten tekst wykluwał się na marginesie naszych dyskusji, na wieczornych zebraniach, w tym małym pokoju w budynku uniwersytetu przy ulicy Tarczyńskiego. Bywało, że Profesor zastanawiał się, czy my siedzimy razem jako ostatni na tym świecie i rozmawiamy o literaturze. Więc porywający styl, ten „kolor” tekstu, jest rekompensatą posępnych warunków duchowych i szarzyzny lat 80 .

Bogdan Balicki: Zapadł mi w pamięć pogląd Kuźmy, notabene dotyczący regionalizmu, według którego wszyscy niedługo przejdziemy na język angielski. Czy moglibyście się do tego odnieść?

12 Autor i jego wcielenia: szkice o roli autora w literaturze.

13 E. Kuźma, Wokół poetyki rewolucyjnej, „Almanach Humanistyczny” 1989, z. 11, s. 20-32; przedruk [w:] idem, Między konstrukcją a destrukcja, Uniwersytet Szczeciński, Szczecin 1994. 
Sławomir Iwasiów: Wydaje mi się, że trzeba poważnie traktować w tym duchu wysnute przewidywania Erazma Kuźmy. W jego teorii faktycznie jest coś takiego, co pozwala myśleć, że doskonale potrafił antycypować pewne tendencje humanistyki, nie tylko w skali lokalnej, ale także globalnej. Kluczowa wydaje mi się w tym wypadku książka Mit Orientu i kultury Zachodu w literaturze XIX i XX wieku ${ }^{14}$, z której dałoby się wywnioskować, że zachodnia kultura wytworzyła sobie, między innymi przez literaturę, kompletny obraz Wschodu - na poły prawdziwy, na poły zafałszowany. To przecież idea bliźniaczo podobna do głównej tezy Orientalizmu Edwarda W. Saida, który ukazał się zaledwie dwa lata przed książką Kuźmy. To świadczy o formacie Profesora - jako teoretyka - „przeczuwającego" pierwszą falę postkolonializmu.

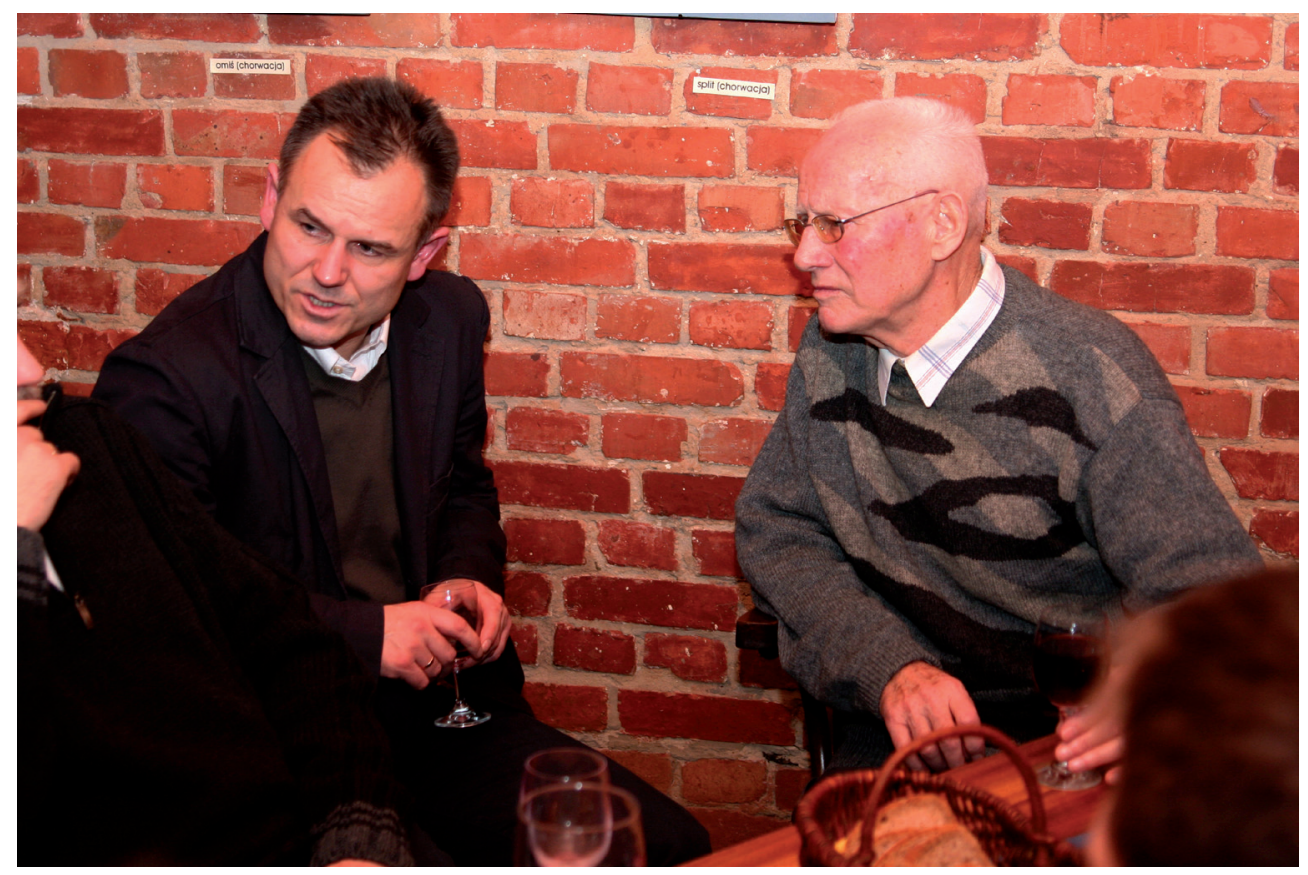

Jerzy Madejski: Mit Orientu i kultury Zachodu w literaturze XIX i XX wieku, z pewnego punktu widzenia, jest komplementarną, całościową konstrukcją. W sumie takich książek się raczej dzisiaj nie pisze. Na czym polega jej wyjątkowy charakter? Po pierwsze, tom ma strukturę opartą na myśleniu opozycjami, z wyrazistą antynomią Wschodu i Zachodu. Po drugie, Kuźma tę opozycję rozpisuje na zagadnienia literackie i społeczne - zajmuje się publicystyką, krytyką, polityką, ale przez pryzmat dwóch stuleci, począwszy od romantyzmu. Po trzecie wreszcie, uwagę zwraca w tym tomie relacyjne w jakimś znaczeniu konstruktywistyczne i do chwili obecnej żywe - ukazanie Europy „między Wschodem a Zachodem” - i dlatego jest to dzieło inspirujące, bliskie rozpoznaniom Saida. Mit Orientu może być rozpatrywany jako „postkolonialny” właśnie w tym sensie, że stanowi wyjście poza dzieło - poza teorię (strukturalną) autonomii literatury.

14 E. Kuźma, Mit Orientu i kultury Zachodu w literaturze XIX i XX wieku, Szczecin 1980. 
Bogdan Balicki: To kolejny wart uwagi wątek: Kuźma był, jak już powiedzieliście, mocno osadzony w obszarze Pomorza Zachodniego i literatury pomorskiej, natomiast w swoich pracach sięgał znacznie dalej, wykraczając poza lokalne czy regionalne opłotki. Czy można powiedzieć o Kuźmie, że brał udział w szeroko zakrojonych debatach humanistycznych, które nie były uprawianiem nauki „tu i teraz”, ale aspirowały do międzynarodowego formatu?

Jerzy Madejski: Nie sądzę, żeby dało się aż tak optymistycznie interpretować wpływy myśli Profesora. Miał jednak świadomość przyporządkowania regionalnego. Ciekawe i charakterystyczne jest jednak to, że im bliżej przełomu XX i XXI wieku, tym bardziej Kuźma mówił w swoich tekstach jako Pomorzanin. Nie Polak, nie Europejczyk, ale Pomorzanin. Nie wspominał już nawet o Wielkopolsce. Tak jakby, w jego teorii, w końcu zwyciężył pierwiastek konstruktywistyczny.

Kuźma był jednak intelektualistą funkcjonującym na pograniczu - i miał tego pełną świadomość. W „szkicach pomorskich”, pisanych na przełomie tysiącleci, starał się dawać rozpoznanie tego, kim dzisiaj jesteśmy na tych ziemiach. Sięgał do literatury powojennej, do tekstów współczesnych, najnowszych. Czytał utwory literackie Piotra Michałowskiego, Artura Daniela Liskowackiego, Dariusza Bitnera, Ingi Iwasiów. Nie była to może systematyczna praca krytyczna, ale po okresie lat 60. i 70., kiedy zajmował się konstruowaniem tożsamości szczecińskiej, podtrzymywał zaciekawienie literaturą regionalną.

Ważna była dla niego opozycja: centrum a pogranicze, ale w innym znaczeniu, niż my ją pojmujemy dzisiaj. Dla nas pograniczność nie musi się tłumaczyć przez odniesienia do centrum, dowartościowujemy tym samym wszystko to, co na obrzeżach. Kuźma inaczej, był przyzwyczajony - i tłumaczył to naukowym rozpoznaniem kategorii regionalizmu - że pogranicze zawsze określa się wobec centrum. I przy tym sam siebie widział jako intelektualistę pogranicza. Mówił nawet żartobliwie, że funkcjonuje w Szczecinie jak „Kant w Królewcu”.

Andrzej Skrendo: Erazm Kuźma był umysłem teoretycznym i stąd być może wrażenie, że wpisywał się w debaty o zasięgu światowym. Bez wątpienia wiedział, co w trawie piszczy, był wyczulony na mody w teorii: ale zawsze do tego, co nowe, podchodził $\mathrm{z}$ dystansem i z upodobaniem pokazywał, że nowe to tylko stare w nowym przebraniu. Stosował taki trick: na początku wydawało się, że jest zapalonym zwolennikiem jakiejś nowej teorii, ale na koniec wystąpienia okazywało się, że wręcz przeciwnie - to wszystko starocie wyrażone w nowym języku. Jednak nie zatrzymywał się w tym miejscu, lecz szedł dalej i mówił: stare powiedziane na nowo nie jest po prostu stare, lecz staje się nowe, a nowe powtarzane nazbyt ochoczo szybko zastyga w ustach jako stare. Ostatecznie - nie wiadomo, co jest czym. To naprawdę ożywczy trick: uczył obrotności intelektu, wymagał erudycji, autoironii, swobody. Kuźma uwodził.

Ale czy ktoś o takim usposobieniu napisze grube tomiszcza? Czy ironiści tworzą historię? Być może. Kuźma miał umysłowość podobną do Janusza Sławińskiego, którego zresztą najbardziej spośród polskich literaturoznawców podziwiał. Dzieła Sławińskiego pomijając Koncepcję języka poetyckiego awangardy krakowskiej - to zbiory artykułów. Sławiński tłumaczył tę osobliwość tym, że jest zbyt niecierpliwy, zbyt niestały, że zbyt wiele rzeczy go pociąga naraz, żeby po prostu usiąść i napisać rozprawę od „a” do „z”. Coś takiego było też w Kuźmie, w jego pracy - pewna niecierpliwość, kapryśność, nadmiar autokrytycyzmu. Przeświadczenie, że zbyt wiele słów zostało wypowiedzianych, 
aby jeszcze coś dodawać. Sławiński po 60-tce właściwie zamilkł; Kuźma pisał, ale nie przywiązywał do tego, co stworzyl, wielkiej wagi, choć pisał rzeczy świetne i nigdy nie schodził poniżej pewnego, naprawdę wyśrubowanego, poziomu. Ale myślę, że u Kuźmy ta jakaś niestałość była o wiele bardziej rozwinięta niż u Sławińskiego. To być może sprawiło, że nie stał się on badaczem tego formatu, co Sławiński, choć bez wątpienia miał porównywalny potencjał. Jest w tym wszystkim jakiś rys niedokończenia, niedomknięcia w twórczości Kuźmy, który nam - z dzisiejszej perspektywy - może wydawać się fascynujący, ale z innego punktu widzenia mógłby być odebrany jako swoista skaza.

Bogdan Balicki: Jaką rolę w rozwoju szczecińskiej humanistyki spełnił konstruktywizm? Co z niego dzisiaj zostało w waszych badaniach?

Andrzej Skrendo: Otóż, według Kuźmy, nie mogło być mowy o postępie w nauce o literaturze. Pod koniec życia Profesor twierdził, że mamy do czynienia z cyrkularnym czy spiralnym ruchem myśli, ciągłym „tasowaniem” ograniczonej liczby elementów. I w takim sensie w jego rozważaniach jest widoczny wpływ teorii konstruktywistycznej: konstruktywizm to „technika”, czy metoda badawcza, którą Kuźma traktował jako rodzaj „ontologii”. To paradoksalne, bo gest uporządkowania i samozakwestionowania był dla niego gestem fundacyjnym - nie może być mowy, twierdzil, o ustanowieniu czegokolwiek bez jednoczesnego aktu podważenia. Coś takiego znajdujemy u Luhmanna, który mówi, że różnica jest bezpoczątkowym początkiem. Żeby to pokazać, Kuźma sięgnąłby do Macha albo do Avenariusa, do Gombrowicza, a skończyłby na Heraklicie. To był niefundamentalistyczny sposób myślenia.

A co z niego zostało dla nas, dzisiaj? Co bierzemy i z Kuźmy, i z konstruktywizmu? Nasza dyscyplina była zajęta piłowaniem gałęzi, na której siedzieliśmy. Upiłowaliśmy ją, a teraz spadamy. Konstruktywizm może nas uratować od upadku, a raczej ograniczyć jego skutki, ponieważ ma narzędzia do tego, żeby przywracać i restytuować niepozytywistycznie pojmowane tradycje scjentystyczne w literaturoznawstwie. Trudne do przecenienia jest w tym wypadku konstruktywistyczne „otwarcie” literaturoznawstwa, przede wszystkim na naukę o mediach. Zwięźle rzecz ujmując: inspiracja płynąca z różnych nurtów konstruktywistycznych może ocalić literaturoznawstwo, czy w ogóle humanistykę, przed odejściem w niebyt.

Spisali i opracowali

Bogdan Balicki

Stawomir Iwasiów

Na zdjęciach: prof. Erazm Kuźma Autor fotografii: Jerzy Wojciechowski

Jerzy Madejski, dr hab., prof. na Wydziale Filologicznym Uniwersytetu Szczecińskiego. Redaktor naczelny (z Ingą Iwasiów) pisma „Autobiografia. Literatura. Kultura. Media” (Wydawnictwo Naukowe US). E-mail: madejski@interia.pl.

Andrzej Skrendo, dr hab., prof. na Wydziale Filologicznym Uniwersytetu Szczecińskiego, teoretyk i historyk literatury, krytyk literacki, dziennikarz. Kierownik Zakładu Mediów i Komunikowania na Wydziale Filologicznym Uniwersytetu Szczecińskiego. E-mail: skrendo@poczta.onet.pl. 
Sławomir Iwasiów, dr, literaturoznawca, krytyk literacki, dziennikarz. Adiunkt w Zakładzie Mediów i Komunikowania Instytutu Polonistyki i Kulturoznawstwa Uniwersytetu Szczecińskiego. E-mail: siwasiow@wp.pl.

Bogdan Balicki, polonista, badacz komunikacji, konstruktywista. Zajmuje się systemową analizą wytwarzania rzeczywistości medialnej. Pracuje w Zakładzie Mediów i Komunikowania Uniwersytetu Szczecińskiego. E-mail: bogdanbalicki@gmail.com. 